\title{
Papers
}

\section{The baby boomer market}

Received (in revised form): 2nd April, 2006

\section{Linda Jane Coleman}

is a professor of marketing at Salem State College, Salem, MA, USA. Her research interests include marketing in international arenas and services marketing. She has published numerous articles in these and related areas. Professor Coleman has presented papers at national and international conferences. She teaches principles of marketing and international marketing.

\section{Marie Hladikova}

is a recent graduate of Salem State College, Salem, MA, USA, with a degree in International Business. Her primary research interest is in the area of international marketing. She has published and presented papers at national and international conferences. She currently works as an operations manager at the Boston, Massachusetts Office of International Trade and Investment.

\section{Maria Savelyeva}

is an MBA candidate at Salem State College, Salem, MA, USA.

Abstract This literature review discusses the maturing of the baby boomer generation and the way this large segment of the population is affecting the workplace and the marketplace. As baby boomers tend to have active positions in life and to be potent employees and consumers, it makes economical sense to invest in retaining them in the workplace, and creating and promoting a vast variety of products and services especially tailored for their needs, using marketing methods that are also tailored to this cohort. Some businesses are beginning to move in this direction. This trend is not only observable in the USA, but also in many other countries. In the future, marketing to this population should use segmentation strategies based on psychographics, as well as demographics. Thus, further study of baby boomers' attitudes, interests and opinions is necessary.

\section{INTRODUCTION}

This is a review of recently published marketing research and news reports dedicated to the baby boomer generation. The goal of the paper is to present a detailed picture of the current status of baby boomers - to describe their lifestyle, with insight into their interests, perceptions, attitudes, opinions; to provide some awareness of how to reach this market effectively, with what kind of products, services and marketing plans; to examine businesses' current responses, their plans for the future and the effectiveness to date.
The baby boom after the Second World War took place in many nations, the USA, Japan and European countries among them. Today, baby boomers form a significant portion of the population of these places. This generation has recently begun entering retirement age, causing major shifts in demographics, economies and, therefore, in business plans and marketing activities.

There are a lot of people in this generation who, in a certain sense, manage to stay young: they are excited by the opportunities to discover new careers, new technologies, new cultures. 
They continue to grow professionally, take on new hobbies, travel to remote continents. With modern means of learning and communication, medicine and financial planning, these people want to and can participate actively in life. The unique way in which baby boomers are greying is likely to change the whole meaning of being over 50 years old.

Some marketers have begun to recognise that boomers deserve the intensive attention of product makers and service providers: this generation has desires to fulfil and wealth to dispose of, and according to some researchers, these factors will remain.

The majority of businesses, however, stick to their habit of focusing exclusively on the young and disregarding the older. This has always been a rather poor choice in terms of ethics; it may very soon become a poor choice in terms of commercial success.

Now is the right time to stress the importance of further studying the baby boomer market, forecast its development and explore its opportunities.

\section{THE MARKET}

Baby boomers have been pioneers and agents of change throughout their lifetimes. This is a description by Anne Thompson: ${ }^{1}$

'They were America's first mass market and an advertiser's dream: 77 million baby boomers that came of age with television. As kids, they were consumers of baby foods and breakfast cereals. As adults, they were trendsetters. But as they outgrow the desired 18 to 49-year-old demographic, they are creating a new frontier for marketers'.

Some businesses are leaving the baby boomers that used to be their primary source of income and planning to court the next consumer. ${ }^{2}$ However, Brent Green, the author of Marketing to Leading
Edge Baby Boomers, believes that the businesses that continue to pay attention to this ageing population are going to be monetarily rewarded. ${ }^{3}$ Green recommends that marketers dispose of traditional concepts about selling to the elderly; he forecasts that retiring boomers will revolutionise the face of marketing.

Green notes that it is often held that boomers, as a market, do not need additional attention because their brand loyalty supposedly remains permanent or even solidifies and hardens. But this is a mistake: research shows that brand loyalty varies by product category more than by age. A boomer 'might be slow to give up Colgate toothpaste, but in other categories such as automobiles or clothing, boomers have shown to have greater brand loyalty than any other generation. They are willing to try new products'.

A couple of common misconceptions may explain the unimpressive corporate response to this large consumer cohort.

Davis supports the view that the post-Second World War boomer generation transforms every age and stage it passes through. He writes that as children, boomers ushered in disposable diapers and strained spinach in jars. As teens and young adults, they introduced long hair, tie-dye clothes and rock-and-roll music to popular culture. When they became parents, car manufacturers rolled out minivans and sports utility vehicles. Today, market researchers are at work studying the likes and dislikes of a generation in mid-life with the notion that they will also transform what it means to be retired. 'Marketers are just beginning to grasp the nature of a society where 1 in 3 adults will be 50 or older by 2010', says Green. 'We have to completely reinvent ourselves in understanding the middle-aged and older markets because they're critical to business success in the future'. ${ }^{2}$ 
An online newspaper article reports: ${ }^{6}$

'Emma Shulman is a dynamo. The veteran social worker works up to 50 hours a week, recruiting people for treatment at an Alzheimer's clinic at New York University School of Medicine. Her boss, psychiatrist Steven H. Ferris, dreads the day she decides to retire: 'We would definitely have to hire two or three people to replace her', he says. Complains Shulman: "One of my problems is excess energy, which drives me nuts". Oh, one more thing about Emma Shulman: She's nearly 93 years old. Shulman is more than one amazing woman. She just might be a harbinger of things to come as the leading edge of the 78 million-strong Baby Boom generation approaches its golden years. Of course, nobody is predicting that boomers will routinely work into their 90s. But Shulman - and the better-known oldsters like investor Kirk Kerkorian, 87, and Federal Reserve Chairman Alan Greenspan, 79 are proof that productive, paying work does not have to end at 55,60 , or even 65 '.

This ageing, bright, productive generation of older Americans will more than likely make a large contribution to the economy, and not be a burden, as many forecast. ${ }^{7}$ The baby boomers born between 1946-1964 are familiar with surfing and shopping on the web. They have increasing buying power, with diverse needs and interests, which vary from annuities to health products. ${ }^{8}$

As Kevin Corke informs, a poll conducted by Princeton Survey Research between 7th March and 11th April, 2005 revealed that the majority of baby boomers were considering new careers and working into their retirement years. 'Among the 1,000 people surveyed between the age of 50 and 70 : seventy-eight per cent wanted to help the poor and elderly, fifty-six per cent wanted to work in health care, fifty-five per cent wanted to work in education'. And these aspirations are so well timed! Corke points out that in the coming decade there will be a necessity for more that 1 million new teachers and 600,000 new nurses, and also for numerous skilled non-profit leaders. 'They need to continue to bring in an income to make ends meet', says Marc Friedman, the founder and president of Civic Ventures, a group that encourages baby boomers to use their experience for positive change in society. 'At the same time, they want to live a life that still matters. They want to keep contributing, they want to have a reason to get up in the morning, and they want to be connected to other people'. ${ }^{10}$

\section{THE CHANGING TIMES}

Until recently, the majority of promotion and marketing actions was tailored for the young. However, addressing baby boomers makes strategic and economic sense. Weimann argues: ${ }^{11}$

'Mountain Dew's "Do the Dew" and Nike's "Just Do It!" were typical advertising campaigns of the 1980s, 1990s, and early 2000s. If people were not hip, young, and cool, they did not exist and advertisers did not target them. But as one famous baby boomer said, "The times, they are a-changing".

One of the largest under-tapped markets in the United States (US) economy today is the baby boomer generation. They have a disposable income valued at $\$ 28$ trillion and a median net worth of $\$ 112,048$ - about 15 times the $\$ 7,240$ reported for those younger than 35 . By 2010, one in three adults in the US will be age 50 or older. Look at these statistics:

$-18 \%$ of boomers have hearing loss

- only $12.5 \%$ of boomers who need hearing aids have them

— the majority $(65 \%)$ of people with hearing loss are under retirement age

- for every decade after the age of 55 , the risk of stroke doubles

- one-third of all strokes occur in people in the baby boomer generation 
Baby boomers respond to messages that help them improve their lives. They seek ways to maintain a healthy, active, energetic, and engaged lifestyle. Although the calendar says the boomer has reached middle age, many in this group view themselves as closer to rock climbing than retiring.

They are not set in their ways either. It is a fallacy that boomers are less likely to try new services or products. Rather, marketers are finding that boomers are open-minded and willing to try new brands, products, and services just as readily as younger generations. Eighty-seven per cent of baby boomers are high school graduates and more than 50\% have attended college. They are critical consumers who have high expectations but are willing to spend money if it improves their health or quality of life. The best way to impress boomers is to provide excellent service, promote outcome data that indicate patients are benefiting from services, and to provide quality devices'.

\section{BOOMERS WORKING LONGER}

In the USA, there has been a new trend in retirement since the mid-1980s, says an article by Coy and Brady: American seniors tend to postpone retiring and continue working. ${ }^{12}$ That is something unusual for citizens of a wealthy nation, and quite the opposite of what had been happening previously:

'For most of the 20th century, retirement ages fell as life spans grew. The trend seemed unstoppable: While in 1950, $46 \%$ of men 65 and older were in the labor force; by 1985 the fraction had plummeted to 16 per cent. An influx of women into the labor force only partially offset the overall decline.

However, starting in the mid-1980s, something highly unexpected began to happen: The trend reversed, and older Americans chose to keep working. The upsurge accelerated even in the weak labor markets of recent years. The share of men 65 and over in the labor force is back up to almost 20 per cent - the highest since the 1970s'.
What is causing the phenomenon? Coy and Brady explain: ${ }^{13}$

'In part, the latest up tick in working ages can be blamed on the stock market's drop from its 2000 peak, which dented retirement savings. In addition, fewer workers have good defined-benefit pension plans, which would allow them to retire young.

However, financial need cannot be the whole reason older Americans are working more. Federal Reserve surveys show that older families have been getting richer, not poorer. The average net worth of families headed by 55 to 64-year-olds soared by 74 per cent from 1992 to 2001, after adjusting for inflation, and likely has gone up since then.

At least as important is that many institutional barriers to working longer are gone. In 1986, in the name of equal rights, Congress banned mandatory retirement for all but a handful of workers, such as airline pilots. Moreover, $401(\mathrm{k})$ plans, which are gradually replacing defined-benefit plans, do not induce people to retire at a certain age'.

\section{THE BABY BOOMERS - THE NEW SENIORS}

Baby boomers are likely to find their own way to spend their retirement time: they may dedicate it to exploration of new career and leisure opportunities. According to Kristin Davis, the ageing market is going to disrupt the status quo: ${ }^{14}$

'For starters, boomers expect their 60s and 70 s to be a time of rediscovery and reinvention, a period when they can pursue hobbies and try new things. "Half of all boomers live in households where the kids are gone", says Steve Audette, a marketing executive in the meals division of General Mills Inc. "They are rediscovering what it is to be single or a couple again." That is why the food company's Progresso soup commercials feature older adults learning Japanese or taking a pottery class. General Mills also targets empty-nest boomers with 
Pillsbury dinner rolls and Green Giant vegetables that are packaged in resealable freezer bags to allow for several small portions'.

Most boomers say that during their retirement they will be working - but in a specific way, on their conditions. Davis notes: ${ }^{15}$

“"When I retire, I hope to expand the volunteer work I currently do, take a part-time job at Barnes and Noble or Borders - more to stay active than for the money - and spend more time traveling and going to museums", says Mary Medland, a 52-year-old freelance writer in Baltimore. Medland's intentions are echoed in a recently released Merrill Lynch study that found that 76 per cent of boomers said they would probably hold down a job in retirement, and a majority of that group said they expected to cycle back and forth between leisure and work. "Retirement for this generation will be redefined as a turning point", says Ken Dychtwald, president of the San Francisco consulting firm Age Wave. "Somewhere near 62 or 64 , they'll leave their primary career and maybe even enjoy the luxury of a year off. Then they will launch into a new chapter in their lives", says Dychtwald, who helped Merrill Lynch - which recently unveiled a marketing campaign aligned with those expectations - conduct the study. That new chapter might be a volunteer stint or low-stress part-time work or the "fun" careers they have always wanted to pursue'.

\section{EMPLOYERS RESPOND}

Do companies appreciate senior employers' talents and skills? According to Coy and Brady, the answer is both 'yes' and 'no': some companies treat baby boomers as their important capital, others do not bother: ${ }^{16}$

'Consolidated Edison Inc., a New York power company with an aging workforce, is trying to hang on to its valuable older workers with benefits like an eldercare referral service and career-long training. It wants to retain the experience of workers like Frederick R. Simms, 67, an emergency field manager who has seen just about everything in his 49 years with the company, from water main breaks to the collapse of the World Trade Center. In a job where trust and rapport are vital, Simms is on a first-name basis with Fire Dept. officials and other emergency workers all over Manhattan. Con Ed recently sent him for a two-day "working people-smart" class, "I do not have the zip I used to have, but I am good enough to work 16 hours if I had to today", says Simms, adding: "I know the company likes having me around".

It is common these days to find older workers on the sales floor of retailers like Home Depot Incorporated and Consumer Variety Store (CVS) Corporation, but what's new is the growing presence of older workers in high-pay, high-productivity careers. MITRE Corporation, a research and development outfit in Bedford,

Massachusetts, is worried about losing its expertise in fields such as radar, which is something of a lost art for young engineers. So it brings back retirees on what it calls a "part-time, on-call" basis. The Energy Department's National Energy Technology Laboratory in Morgantown, West Virginia, also recognized the value of older workers with technical expertise. It has clung to chemical engineer Hugh D. Guthrie, 86, as a full-time technical adviser in part because he has ideas that younger engineers might never think of. Says Guthrie: "My experience gives me a perspective on questions, which may not always be right but nearly always will be different. The greatest service I provide is in stimulating the thinking of people involved in a project."

Unfortunately, many other companies have not gotten the message. The Society for Human Resource Management, an association of personnel execs, says 59\% of members surveyed do not actively recruit older workers and $65 \%$ do not do anything specific to retain older workers. The Bureau of Labor Statistics found in 1995, the last time it looked, that workers age 55 and up got only one-third as many hours of formal 
training as workers 45 to 54. Marian Stoltz-Loike, CEO of Senior Thinking Limited Liability Company (LLC), a consultancy, says executives often are not even aware that older workers are getting a subtle message that training is not for them'.

In the modern working environment, it is often important that employees can use information technology effectively. Perhaps older workers are not showing such a capability? The article states that although seniors tend to operate information technology more slowly, they make fewer errors. It seems that by not providing training to older workers, businesses lose opportunities. ${ }^{17}$

\section{REDEFINE THE WORKFORCE}

According to Coy and Brady, baby boomers will be more likely to boost the economy than be a drain on it. ${ }^{18}$ Even though people are traditionally less active as they age, new research indicates a change with the next generation of older Americans. The forecasters suggest that the boomers will be very active, innovative and productive long after those seniors before them, and will continue to be, far into and after normal retirement years. The economy, employers and society will all benefit because of the resulting increased standard of living. Thus, there will be a reduced financial burden on Social Security and Medicare. Legal roadblocks and restrictive practices of corporations need to be revisited and revised to realise the powerful potential of this significant market.

Coy and Brady predict that as more Americans reach their $60 \mathrm{~s}$ and $70 \mathrm{~s}$ in the years to come, many will be willing to work, at least part-time. ${ }^{19} \mathrm{New}$ information is surfacing that work can help people remain mentally and physically fit rather than wear them out.
Because of the demand for their skills, more and more professionals, such as physicians and lawyers, are already working into advanced years. Because boomers are more educated than any other generation in history, the pattern of working longer is bound to continue.

The two writers suggest that with today's ever-changing knowledge and information, and the need for refresher training programmes, it is no more complicated to include older workers along with the young ones.

Another significant point of Coy and Brady's study is that advances in medicine are enabling people to continue their good health and be productive in the workforce for longer. The authors state that technological development, gradually liberating people from physical labour, diminishes negative effects of ageing on employee productiveness: the less physical tasks are demanded, the better results older workers can deliver. They also note that access to vast internet resources reduces the volume of information to memorise, which can be of great assistance to the older generation.

'Assuming that the improved health trends continue, boomers should be able to work productively into their late $70 \mathrm{~s}$ if they choose to', says Elizabeth Zelinski, Dean of the Leonard Davis School of Gerontology at the University of Southern California. Some enlightened companies are hiring or retaining older workers with flexible work schedules and ample training. ${ }^{21}$

\section{MARKETERS RESPOND}

The challenge to businesses for the years to come is to observe and respond to ageing consumers while conducting research into the mental make-up of those nearing 60 and beyond. Previous notions, stereotypes and misleading 
information need to be discarded for more recent and accurate information. These past impressions should be put aside until more is known and more appropriate products and services are developed.

More established businesses are repositioning themselves to meet this challenge. Yet, despite the demographic imperative, large numbers of businesses have still not got the message. They cling to the concept that the 18-49-year-olds, the demographic still used as a standard in the advertising business, are the most desirable age group to reach. The stereotype persists that once people reach the age of 50 years, they have fewer needs, are unwilling to try new products and have little buying power. Timmermann says that some of the businesses that have discovered the baby boomers are focused primarily on those who have the most money - on the Jaguar-driving, spa-going luxury market. ${ }^{22}$

Baby boomers range from the employees to the owners of small and large businesses. Some are retirees but, no matter what, they are all consumers. They are all looking to satisfy their needs and increase their quality of life. The needs of the baby boomers cover all ages and incomes within this market. They are significant consumers, whether shopping for necessities or luxury items. They buy products for their grandchildren, and health supplies and trips for themselves.

Beginning in 2007, nearly one-third of US citizens (around 78 million people) will be eligible for Social Security. They will be on fixed incomes, increased incomes due to inheritance from parents and/or gainfully employed. Elan believes that one US way of life that will not change is enjoying the social experience of dining out, no matter how old the customers grow. ${ }^{23}$

\section{RETAILERS RESPOND}

It was estimated by the American Association of Retired Persons (AARP) that the individuals aged 50 years and over 'own 80 per cent of US financial assets and dispose of 50 per cent of discretionary income' but at the same time receive only 10 per cent of ad messages - 'seniors, as a consumer group, are largely being ignored'. ${ }^{24}$ According to Embrey, retailers should initially embrace this market by means of senior-tailored selling and employing seniors. The researcher writes: ${ }^{25}$

'In 1900 , only 13 per cent of the population was over the age of 50. By the year 2020, that number will increase to more than 35 per cent - resulting in a huge economic impact that will, no doubt, fuel growth throughout the retail industry.

While some retail channels, particularly drug, mass and dollar stores, have begun shifting focus to senior citizens, the rest of the remaining world have largely ignored this profit-generating demographic.

Convenience stores, especially, have the opportunity to benefit from this growing consumer market with a few simple senior-targeted programs. The difficult issue is getting senior consumers to want to come into the store and, once inside, giving them a reason to want to come back again.

"In some of our locations, east of the beach area, where mostly senior citizens live, they buy a lot of gallon milk, coffee, and newspapers, we have to watch that supply", said Mahammad Qureshi, CEO of MAZ Group. "They also seem to come heavily in the mornings. We sell a lot of the weekend Sunday papers in our heavily senior communities. They carry a lot of coupons, and I think that is a big interest for them." Lottery tickets, which Qureshi said are very popular with senior shoppers, are also big sellers in his stores with these value-oriented consumers.

In 2001, consumers aged 45 and older spent $\$ 2.38$ trillion of the $\$ 4.36$ trillion total consumer spending in the United 
States, according to the American Association of Retired Persons (AARP). That 52 per cent market share was not limited to the growth of baby boomers entering senior territory, but increases of market share of consumers aged 75 and older as well. Today's seniors are spenders. Some say value-conscious spenders, perhaps, but spenders nonetheless.

Today's seniors are healthier and more active than ever. Wal-Mart employs seniors as greeters, and that really impacts their older shoppers. Having seniors as employees in itself would attract other seniors as customers. The fact is that seniors tend to be excellent employees, because they already have the good work habits and they feel useful. They generally require less supervision, show up on time, and are very courteous. In many markets, it is very difficult to find good employees. That could be one of the keys to going after this market'.

Embrey cites the words of Ian Hale, senior vice president of ACNielsen, one of the largest marketing information companies in the world: ${ }^{26}$

\footnotetext{
" "We do think that future seniors will behave differently than past seniors", Ian Hale, Senior VP ACNielsen said. "We've got better educated consumers and a lot more concern with health and wellness than there ever was before. And there are just so many more shopping and buying choices than seniors in the past have had",
}

As for financial service retailers, 'some banks are acutely aware of baby boomers and have retooled themselves to cater to older customers, and a different breed of them', states Kuehner-Hebert. ${ }^{27}$

'Nowadays older people really are interested in more than a free account; they are interested in how their bank can help them finance their lifestyle. They have much more disposable income, and they are more on the go than earlier generations have ever been. ${ }^{28}$

\section{AUTOMOBILE INDUSTRY}

There is always the urge to serve the youth. But nowadays it is not necessarily the best strategy: another market is rapidly growing. As Crain points out, just as some cars are great for the youth, there should be great cars for the elderly. ${ }^{29}$ The automobile industry must embrace the baby boomer market and address their changing wants and needs. Companies should invent products that this market will understand, appreciate and prefer - with features such as ease of getting in and out of the automobile, gauges that are large and easy to read, controls that are large and easy to grasp. Crain suggests that one problem is that manufacturers are unwilling to admit to engineering and designing cars for an older market. In marketing terms, this would appear to be a death wish. Every manufacturer is trying to push its typical customer's age lower and lower. But baby boomers, rapidly becoming part of the greying generation, deserve a car, or cars, of their own.

A study demonstrates that some companies are already recognising and addressing this issue. ${ }^{30}$ The General Motors Corporation brand has, since at least 1986, tried off and on to attract younger buyers, without much success. Now it is going back after boomers, while also trying to hold onto loyal older consumers. Buick is going after baby boomers again. They began the transformation with the new 2005 LaCrosse midsize sedan, and the new Terraza sport-utility-looking minivan. Buick is confident that the two new models will attract baby boomers. A Buick dealer said he sold the first three LaCrosse sedans he acquired; all of the buyers were in their early 60s. Buick's research with baby boomers, mainly import owners, showed that they had a favourable image of the brand but felt that Buick did not make vehicles for 
them. Buick showed this group LaCrosse without the Buick name, and Lexus was the most frequent guess.

Aiming for the younger end of the baby boomer generation, Toyota will be giving a freewheeling spin to its estimated $\$ 35 \mathrm{~m}$ campaign for the redesigned Avalon. The effort seeks to provide the somewhat staid model with a more youthful, even bohemian, image, with a design and language that evokes the late 1960s. The push comes as sales of the 11-year-old Avalon fell 28 per cent in 2004, according to Ward's Auto Info Bank, due to competition from a redesigned Nissan Maxima and Chrysler's 300 in the full-size sedan category. The latest campaign presents the first Avalon upgrade in four years. The new model sports a rounder, more contemporary profile. Toyota is hoping to lower the median age of the Avalon buyer from mid-60s to low-50s, said Steve Jett, national car advertising and event marketing manager. 'What we want to communicate is the fact that this car is an affirmation of their zest for life', he said. 'So we wanted to do it in a way that's inspiring, very uplifting' ${ }^{31}$

According to Winter, Lincoln, known for having some of the most elderly customers in the industry, promotes its new Lincoln Mark LT pickup. 'For years auto makers have desperately pursued the youth market and treated customers over 60 as if the only transportation they aspired to were gold-plated walkers'. ${ }^{32}$ More automakers are recognising that tomorrow's seniors are going to be very different from those who have gone before. 'For all of our emphasis on youth, we cannot ignore the size and influence of the mature-boomer consumer group', says Don Esmond, senior vice president and general manager of Toyota Division. 'It is an ever-evolving and dynamic consumer base that is constantly looking for product that is new and different. Not only do they have money - they are willing to spend it'. Esmond made his comments while introducing the restyled Toyota Avalon sedan and a new cross/utility vehicle concept named the FT-SX, both specifically targeted at ageing boomers. ${ }^{33}$
'Boomers are not folks who aspire to dodder around gated communities in golf carts or drive to bingo games in Lincoln Town cars. These are consumers looking for adventure. They will want to head out on the highway to travel, camp, and perhaps run a little wild. They will want Choppers, not walkers, minibuses with flowers painted on the side, and God knows what else. Auto makers, better get your motor runnin. ${ }^{34}$

\section{SERVICES}

As stated in a report by Karina Purang, cited in McMillan's work, 'wealth is increasingly concentrated among older age groups and they have become an essential target for financial providers'. ${ }^{35}$ But the providers tend to take this gold mine for granted: 'not enough is being done to entice this age group in terms of developing products tailored to their needs'. ${ }^{36}$ Because 'household insurance is one of the target products for the over 50s' and 'savings and investment are the greatest opportunities', the report concludes that using these opportunities 'can be done by redesigning products and adopting proactive marketing of these products'.

As the New York Times points out, 'giant marketers of financial services ... salivate over the prospects of handling the retirement needs of the generation born between 1946 and 1964: ${ }^{37}$

'Fidelity Investments and Merrill Lynch are among the blue-chip names that are focusing pitches on the boomers, as the oldest of them will soon start to turn 60. The A.G. 
Edwards brokerage firm even centers its new campaign on an oversized egg, with headlines like "You can not ride off into the sunset if your nest egg won't carry you".

"We have been using the positioning of making the financial world clear and understandable from 1998 through 2004", Ms. Susan Crabtree, vice president, says, "but early 2004 we were looking at our markets and how they were changing, especially as the baby boomers are moving to retirement ...".

There is "Hello, Dolly" and "Hello, Goodbye", "Hello Hello" and "Hello Stranger" (shoo-bop, shoo-bop, my baby ooh, as Barbara Lewis cooed.) Now along comes the Lincoln Financial Group with a campaign that greets what is to come with a hearty "hello future". The campaign, with a budget estimated at $\$ 20$ million, got under way in April 2005 with television, print, radio and online advertising; additional commercials are now being added to the mix. The "Hello future" campaign, by Martin/Williams in Minneapolis, part of the Omnicom group, is intended to create an image for Lincoln as the go-to company for the financial needs of the baby-boomer generation as its estimated 76 million members face retirement'.

The newspaper supports the view that the exceptional baby boomer generation has changed everything they have touched, and now it is financial services' turn:

‘... As a result, Lincoln Financial Group changed their whole business strategy. In one LFG commercial spot, a man about 60 is seen on the slopes, helping out the participants in an adaptive ski program, which assists skiers who are disabled. He returns home and tells his wife: "I think my dad was wrong. Maybe I do have a future as a ski bum". The announcer declares:

"Retirement is not an end. It's the start of what you were meant for all along. Go grab your skis and say, Hello future."

In a second commercial, the owner of a garage that works on classic cars tells a customer he is selling the place because "I decided I have got to chase the dream before I get too tired to do it". Fast-forward to the new owner, an older gentleman, who says he bought the garage for the very same reason. "Maybe you will finish your life's work early", the announcer says. "Or maybe you will hear a second calling and say "Hello future'."

In a third commercial, a girl is sitting in her guidance counselor's office in high school, circa the 1960s. "Roberta, I can see you as a file clerk", he tells her. "It is a great way to meet eligible lawyers." Fast-forward into the future, as she becomes a lawyer, then a judge, then retires. The scene shifts to a present-day student in her guidance counselor's office. "File clerk?" a voice asks. "Have you ever considered being a lawyer?" The camera cuts to the counselor who is, of course, the retired judge. "That one thing you always wanted to do", the announcer says, "it is out there just waiting for you to say, 'Hello future'."

The idea behind the campaign is "to capture the notion that retirement is not shuffleboard, sitting on lawn chairs outside mobile homes in Florida", says Tom Moudry, executive vice president and executive creative director at Martin/Williams'.

\section{E-COMMERCE}

The internet has become a powerful instrument that facilitates and enriches almost every realm of modern life. Not only the young use the internet - as a study reveals, 'for many over 50 s, the web is a key communication tool to a more inclusive lifestyle'. ${ }^{38}$ Stroud says:

'The number of older people using the internet varies widely by country. In the US nearly 70 per cent of 55-64 year olds are users while in Spain only 11 per cent are connected. Penetration rates in the United Kingdom (UK) and Germany are somewhere between these two extremes. Like so much market analysis, this data ignores people aged 65 and older. However, this is an improvement on the latest internet research from the European Union that assumes life 
stops at 55. Past the age of 65 there is a significant fall-off in internet use. In the United States approximately 25\% of the over-65s are connected. In the UK only $15 \%$ of over- $65 \mathrm{~s}$ use the internet. Members of this age group left the workplace before the web became widely adopted, which is the main reason for such low levels of use'.

As we have seen, baby boomers are active and wealthy customers. One of the ways that businesses may increase sales volume is making their online interfaces reachable and readable for this major consumer group. Stroud comments: ${ }^{39}$

'It is rare for designers to understand how to create websites that work equally well for all ages. On the whole, websites are built by the young for the young, taking no account of older people's requirements ...

The prime requirement when visiting a website is that it is simple to use and delivers what is required, in as fast and painless way as possible. The world's most popular and easiest to use website is Google. Its home page contains 37 words. Over the past couple of years it has added just five words. Most companies do not share Google's obsession with retaining the structure and simplicity of their websites. The presence of moving images makes it difficult for older people to concentrate and make decisions as they navigate a website. Research shows that older people find goal-centered navigation the easiest to use. This type of navigation is structured around the goals that people have when they visit a site'.

In fact, the features described above make websites more convenient for younger people as well. Stroud asserts:

'Website design is one area where teenagers and their parents agree. The difference lies in their disposable income. And if you accept the arguments about the economic importance of older consumers then optimizing your website for their needs should be an obvious business decision'.

\section{BRAND LOYALTY}

An online article by AdAge.com provides the following numbers that once again confirm the necessity to intensify promotion to seniors: ${ }^{40}$

'The $50+$ crowd is the fastest growing market segment in the US, with projected growth from 76.1 million adults in 2000 to 97.1 million by 2010 - an increase of 27 per cent (US Census, Populations Projections Program, 2000). And based on a study conducted by AARP and Roper ASW in 2002-03, the $50+$ market's loyalty for brands in various categories is often on par with the 18-49 market, which means that they are just as fickle when it comes to brand loyalty as the young demographic, but with substantially more income. In fact last year alone, they spent nearly $\$ 400$ billion on things like travel, apparel and beauty products. And with 10,000 people turning 50 every day, their spending spree is just starting. This demographic has high discretionary income and is just as open to trying new brands as 18 to 49 year olds'.

\section{THE DEBATE GOES ON}

Much is heard about how ageing baby boomers are strikingly different from their parents at comparable ages. The differences between boomers and their parents have strategic and tactical importance to anyone wanting to serve this newly senior population.

But some say that boomers are merely following their parents' patterns of buying, working and living, and that boomers' needs and actions have been evolving, and will continue to evolve, in the same way as their parents' at comparable ages. ${ }^{41}$

Then there is the more optimistic vision of ageing in the USA, which stands in sharp contrast to the conventional wisdom. The optimist vision of boomer market ageing sees this market as very attractive and with many 
opportunities to serve them. However, the pessimistic pundits expect that boomers will retire in droves soon after hitting 60, as their predecessors did, while those who do keep working will dial back to less challenging and less productive jobs. The fear is that boomers will finally heed Timothy Leary's call, dropping out (of the workforce) and turning on (the television). 'This explosion in the number of elderly Americans will place an unprecedented economic burden on working-age adults', investment banker Peter G. Peterson wrote last year in his latest book, Running on Empty.

Will longer-working boomers block the advancement of younger workers? Maybe. But what worries employers more is the opposite - labour shortages that could emerge if boomers retire en masse and there are not enough people to take their place. The Congressional Budget Office is forecasting that labour-force growth will slow by almost half over the next ten years. ${ }^{42}$

According to NewsTarget.com, other notes of interest are that seniors and baby boomers are struggling with growing credit card debt, and experts expect the numbers to rise as retirement funds fall short and the cost of living spirals even higher. 'We see a lot of older folks on fixed incomes who are finding retirement funds are not sufficient to keep up with the everyday living', said Andy Liles of American Credit Counseling Service Inc. 'They go into credit-card debt trying to pay for their medication'. ${ }^{43}$

The average debt of Americans aged 65 years and older has jumped 89 per cent in the past decade to more than $\$ 4,000$ per person, while those aged 50-64 years have seen their average debt double to the same amount, according to a report by New York think-tank Demos. Many of the seniors who are having credit problems are not there for frivolous reasons, said Sally Hurme of the AARP. It is not because they are charging their trip around the world; it is that they pay $\$ 300$ a month in prescriptions. ${ }^{44}$ The average US couple retiring at the age of 65 years will pay $\$ 190,000$ for healthcare expenses over the next 15 to 20 years, according to Fidelity Investments. ${ }^{45}$

\section{EUROPE}

The demographic situation in Europe is similar to that in the USA: Europe is greying. And, only recently, marketers have begun recognising the necessity to address the older population. Boyer King writes: ${ }^{46}$

'The number of consumers aged 55 and over will grow by 60 per cent in the next 15 years, whereas the under-50 age group will remain stable. Unless they are in the business of selling retirement homes or hearing aids, companies have turned a blind eye to this graying market. While these "seniors" are more active and spendthrift than ever before, 86 per cent feel that advertising is not aimed at them. This is not a mere feeling, it is a fact: according to a report published in the Economist magazine in 2002, companies still spend over 95 per cent of their marketing and advertising budgets on the under-50 age groups.

"Marketing for seniors is definitely behind the European age pyramid", says Frederic Serriere, head of Senior Strategic consultancy and author of several books on marketing for seniors. "There is a growing awareness that this market is important, but people do not think they have to look into it now. It is going to take some time."

"We are in a society where there is strong preference for young people", writes Jean Paul Treguer, founder of Senior Agency, an advertising consultancy for seniors, on his company's website. "Large worldwide corporations like Coca-Cola, Walt Disney, Sony and Nike were born in the 20th century, and they contributed to define the 
core target for advertising as 15 to 35 year olds."

Many brands do not want to be associated with strictly senior products. "If an advert is geared towards a senior market exclusively, it often harms the product", says Serriere, explaining that a brand may not want to advertise in a magazine geared exclusively to seniors for fear of being associated with "old people" brands, which may damage their image. "These brands don't want to be linked to other 'senior' products", he adds. Serriere believes that attracting the over 50s requires not only adapting the advertising message, but a long-term strategy. "You need a global vision",.

Nevertheless, some businesses are tuning into the older market, as Boyer King points out:

'France counted 146 commercials aimed at seniors in the media in 2002, a comparatively small number compared with the total number of commercials, but a significant increase from previous years. Lastminute.com included the senior category in their marketing strategy in France for the first time in January. Danone, French food and beverage multinational, is currently targeting seniors with its "immunity boosting" yogurt drink, Actimel. In 2001, cosmetics giant L'Oreal recruited Catherine Deneuve, the 61-year-old film star, to be the face of a hair-treatment product'.

Another example of changing times is the growing popularity of a modelling agency founded in Munich. The agency works with corporate clients that employ older men and women. Over the past few years, the founder and director of the agency, Christa Hohs, has seen her business literally take off. Boyer King reports: ${ }^{47}$

'Created in 1994, Senior Models has opened branches in Berlin and Spain, and is looking to expand into Italy next year. "At the beginning, we started with pharmacy-clients mostly", explains Christa Hohs, an energetic 62 -year-old and former senior model that began her modeling career in her 50s. "But over the years we got more and more insurance, cars and bank companies as clients. Today there is no branch we do not service - except fashion! But we started getting interest for fashion models this year for the first time"”.

Perceptions of the over-50s in the media seem to be changing too: ${ }^{48}$

'Seniors may never make it to the front pages of mainstream women's magazines, but estimates suggests that by 2015, the over-50s will account for between 50 to 60 per cent of all incomes. Unless companies put serious thought into targeting these consumers, they could find themselves losing out as Europe's seniors come of age'.

\section{JAPAN}

The post-war baby boom embraced many world regions and countries, Japan among them. According to Taiga Uranaka's article, 'in Japan baby boomers are defined as those born between 1947 and 1964'. ${ }^{49}$ The article indicates that Japanese governmental institutions estimate boomer population 'at 6.8 million, roughly 30 per cent to 50 per cent more than their counterparts in the neighboring three-year brackets'. Here are some facts about what the boomer generation has faced while maturing: ${ }^{50}$

'The boomer generation has had a significant impact on society and the economy at virtually every stage of their lives. Born when the country was still recovering from the ravages of war, they reached school age only to witness a serious classroom shortage. Later, fierce competition to enter high schools and universities became a social problem. As grownups, they formed what was touted as the 'new family' and helped launch a housing boom, urbanization and a mass consumer culture. "They represent the 
history of the country's postwar economy", observed Yoshio Higuchi, a professor at Keio University in Tokyo who studies baby boomer issues.

The generation joined the workforce around the time the country's breakneck economic growth suffered a setback from the oil crises of the early 1970s. Still, Japan enjoyed relatively moderate growth, and the baby boomers played important roles in the workplace, helping the country become an economic superpower. "The generation was large in number, but it also had leadership qualities", Higuchi said, adding the baby boomers were the last generation to truly start and complete their careers amid the traditional "guarantee and obligation" relationship with companies: lifetime employment in exchange for loyalty.

"We are easy-going and even frivolous", he said. "The older generation sees us as childish — a bunch of comic-reading, television game-playing grownups." $\mathrm{He}$ added that he believes his generation is much more Americanised and liberal than those born after them, largely due to its exposure to the US dramas that dominated television and an "undiluted postwar democratic education". "We grew up watching American television programs such as 'Route 66"', Higuchi said. "And we are the ones who sing American songs by Nat King Cole and Elvis Presley at karaoke bars, while youngsters sing Japanese pop",.

Having been the major part of the workforce, boomers in Japan will affect the society once again - by their retirement. Uranaka elucidates this issue: ${ }^{51}$

'A mass exodus looms in 2007 when baby boomers begin reaching retirement age, and the implications - both positive and negative - will be far-reaching. While concerns mount over the loss of skilled and experienced labor, many view the situation as a business opportunity because it signifies an emerging consumer group with a lot of free time and retirement bonuses to burn. First and foremost, the mass retirement will impact the labor market.
"All conditions being equal, the country's worker population will decrease by 1.32 million in 2010, compared with 2004", said Ryutaro Kono, chief economist at BNP Paribas Securities Limited (Japan). "The labor supply will get tight". In addition, Kono predicted, the tight labor supply would help improve the status of female workers, because businesses will be more hard-pressed to retain talented employees regardless of gender.

But the household savings rate will decline as baby boomers retire and start living off their savings. Some economists worry this will adversely affect capital investment, since the pool of savings at banks has been the main source of cheap funding for businesses. Kono, however, said he is not concerned, noting that in the age of globalization, companies can procure capital from overseas. He said he does not see the mass retirement as detrimental to the economy'.

\section{MARKETERS DILEMMA}

Nyren raises a further interesting point, saying that, along with the obsession with youth, one reason why baby boomers are not being targeted more is that they do not have a short attention span. $^{52}$ They need to know more before they become aware and impressed by a product or service. A 30-second salvo will miss them by a mile. The baby boomer has spent more than 40 years digesting information and deciding what he or she wants. The advertiser who is willing to tell the story of the product has the advantage. ${ }^{53}$

Moxley goes on to say that at some point in the 1960s, someone convinced somebody that one-minute commercials could be exciting, absorbing, mini-masterpieces and do their jobs. ${ }^{54} \mathrm{He}$ says that now might be the time to persuade agencies and clients that this is likewise true for 5-30-minute infomercials if they want to reach baby boomers. The possible added cost of communicating to baby boomers, along 
with the perceived risk, could discourage many from responding to this population. For example, tech companies do not advertise to older people because they think they are late-adopters. ${ }^{55}$

There seems to be a lack of commitment and conviction to target the baby boomers. As with the rising Hispanic population, however, this market must be taken seriously. The baby boom retirement wave is currently a slow-moving trend, but when it hits, it is going to hit fast. This is the advantage of demographic research: it can pick up a trickle before it becomes a flood. ${ }^{56}$ This calls for marketers to pay close attention to this market, believe in its value and be proactive.

\section{IMPLICATIONS}

Baby boomers represent a major - and, moreover, expanding - consumer group in the USA. According to Coming of Age Incorporated, 'baby boomers are turning 50 at an astonishing rate of one every 7 to 10 seconds. That is more than 12,000 each day and over 4 million a year for each of the next 18 years! ${ }^{57}$ Kuehner-Hebart adduces the following statistics: ${ }^{58}$

'By 2020 there will be 115 million people 50 and older in the United States, 50\% more than now, according to Ken Dychtwald, the author of Age Power: How the 21st Century Will Be Ruled by the New Old. Most of them will be baby boomers; more than 76 million people were born between 1946 and 1964, and Americans are living longer'.

Not only are baby boomers numerous but they are also living full lives.

Kuehner-Hebart writes: ${ }^{59}$

'We are seeing a new level of spirit and empowerment among older people. People are going back to school in their 50s, starting new businesses in their 60s, and marrying in their 90s. Marketing strategies should recognize this change. Now that people are living much longer lives, older people span a wide age range and have a very, very wide range of needs'.

Taking into account all of the above, today and tomorrow marketers should focus on the baby boomer generation. The article by Coming of Age Incorporated asserts: ${ }^{60}$

'Demographers point to exceptional opportunities for companies targeting affluent baby boomer and older consumers ... Middle-aged consumers are the wealthiest, best educated and most sophisticated purchasers. They are the single largest consumer group in America. The key to securing and retaining these growing lucrative segments is a better understanding of baby boomers and older consumers and how their behavior, buying motivators and ... needs change as they get older'.

The USA is undergoing a major change: it is greying. But there is such a way to deal with it so that everybody benefits. Coy and Brady say: ${ }^{61}$

'The solution to the demographic shift is staring us in the face. As Urban Institute senior fellow C. Eugene Steuerle told the House Ways and Means Committee in May: "People in their late 50s, 60s, and 70s have now become the largest underutilized pool of human resources in the economy". By working longer - and more productively - boomers will help the US economy thrive even as their personal odometers keep clicking forward'.

\section{REACHING THE BABY BOOMERS}

Some marketers believe that retailers, as well as other businesses addressing baby boomers, should avoid stressing their declining years. Not only because it can be frustrating in general, but also because 
boomers do not associate themselves with old age, as Kuehner-Hebert points out: 'It is best not to use the word "seniors". These people don't think of themselves as seniors. They have this younger mindset, and they think and do many of the things that they did when they were 25'. ${ }^{62}$ Ebenkamp agrees with the above view (2004): ${ }^{63}$

'It should not come as a huge surprise that baby boomers, the generation that took the Peter Pan principle of never growing up to heart, are interested in pursuits viewed as youthful. Captured as the first powerful young economic force of the Television age, boomers have sought the fountain of youth through all stages of life, and incorporated aspects of play and fun into everything from careers to cars'.

Weimann proposes some specific and practical ways to meet and greet the boomers: ${ }^{64}$

- Hold an open house at your practice with food and drinks. Invite local health reporters, referral sources such as physician and dentists, and their spouses, as well as potential consumers who are in the boomer generation. Have product displays, demonstrations, and staff on hand to talk about how your services are relevant.

- Target organisations with a high percentage of baby boomer members such as AARP. Keep your talks brief and simple. Focus on who you are, what you do, and how you can make a difference in people's lives. Do not let your audience leave empty-handed. Give them a brochure, newsletter, fact sheet, or something with your name on it that tells how they can reach you for additional information, or to schedule an appointment.

— Let the baby boomer audience know the benefits of your services. For example, put forward the idea that successful treatment of communication disorders can lead to greater earning power and improve interpersonal relationships. Audiologists can stress that hearing aids are not always for the very old or that they make you old. Rather, they are an instrument that can improve and enhance a person's quality of life.

- For direct mail list, use a company that can provide names of baby boomers in your local area. Names of direct mail list companies are available in local area yellow pages or on the internet.

- Get involved in any local health fair that appeals to the baby boomer segment. Bring materials for distribution.

- Develop professional relationships with local media. Send them a letter and follow up with a phone call. Keep in mind that before reporters can inform the community, you will need to educate them about hearing and speech problems in baby boomers. Provide them with as much background information as you can. Present statistics as well as anecdotal information from your own experience. For example, story ideas could include recent technology advances in the hearing aid industry and communication disorders that affect baby boomers.

\section{ANALYSIS}

This type of attention and sensitivity needs to be applied to the boomers. More often than not, organisations that should be trying to reach this market fail to understand this by not making the extra effort. This cohort has from early on been unique and separated from the patterns of their parents. How best to 
utilise this market? Are the necessary additional time, energy and expense more than marketers want to expend or believe is warranted? Do they believe and understand that it is worth it? Are marketers and managers capitalising on this large and active ageing market? If not, why not? Why are so many companies not taking this cohort as seriously as they should? After all, if the cohort is so large and valuable, why is it being neglected?

Due to the reality that so many of the characteristics of this market and its activities are unprecedented, there is some risk in making certain deductions. Limited hard facts, references and studies can predict the development of some of the existing trends. Some of this market is still wavering on retirement choices; future spending patterns are speculative, as are lifestyle preferences, as they grow older. The cost of their retirement may not allow them to live the lifestyle to which they are accustomed. So, will they use debt to subsidise or a new job? Will greying baby boomers retire en masse or block the advancement of younger workers? Will they be an economic burden to working-age adults? What will they do with their retirement funds that fall short? Borrow, work? Go to the gym?

Marketers are torn between the logical upcoming 'youth market' and the new seniors. The young have always been the prime focus. But the new seniors are likely to be very different to those who have gone before. Marketers must steer away from assumptions made on age.

Companies also need to be cognisant of possible damage from what economists call an internal audience problem: the people who create ads are not like the people who buy advertised products. According to a 1995 survey by American Demographics, the average corporate advertising representative is 31 , and the average ad agency account executive is
28. If the experts who tell companies how to advertise are tykes, it is not surprising that companies are convinced that they should be targeting tykes, too. ${ }^{65}$

When discussing the resistance to change, the chain of events in international automobile market comes to mind. In the 1970s in the USA, there was the tendency to ignore the changing economic trends, energy costs, and consumer preferences and resistance to retooling manufacturing plants. The Japanese automobile industry, on the contrary, took off the blinders, modernised its facilities and offered the world small, economical, quality cars. There was a swing in balance of trade and serving the customer due to their reading the market and risk-taking. In some ways, the US automobile industry is still recovering.

There is a risk in trying to read this major market. What if it is read incorrectly? What if this population is split in their ageing ways, and some retire and borrow, while some work and buy? Much more needs to be watched, learned and studied beyond these discussed speculations and limited proven facts. Much more attention needs to be given to respond appropriately to this unusual market. Companies need to be willing to commit additional funds, whether it be for research, redesigning or advertising to reach this market. There is no precedent, so marketers are in previously unexplored territory and must take a leap of faith in its rewards. As in the speculation of the Chinese market, this one is also large and mysterious but definitely worth the research, patience and attention for a long-term payoff.

\section{RECOMMENDATIONS}

- Conduct research about how to better serve and accommodate older consumers. 
- Empathise with the needs of ageing baby boomers.

- Meet the challenge of improving existing products, services and workplace environments to be more comfortable and accessible for older people without crossing the line to making them feel old.

- Study the older boomers who are already acting, buying and living in ways that can give insight into future behaviour of the younger boomers as they mature.

- Conduct focus groups with the younger boomers, test the market and continually analyse the results.

\section{CONCLUSION}

This market is complicated by the need to understand and appeal to it emotionally and rationally. The motivations and mindset of baby boomers have to be explored in detail. The data received by such exploration will be extremely useful for economical prediction and marketing plan building.

The technique of market segmentation based on psychographics - attitudes, values and motivation - was applied to the baby boomer market as early as 1989. Morgan and Levy came up with nine separate categories of psychographics and attempted to apply them for explaining this market's behaviour. ${ }^{66}$ The research is discussed in their book Marketing to the Mindset of Boomers and Their Elders.

Ten years later, Peter Francese, founding publisher of American Demographics, commented, 'the attempts by marketing executives to reach those over 50 have been miserably unsuccessful'. ${ }^{67}$

Much has changed since that comment was made: today, the strategy proposed by Morgan and Levy may be the best way to approach the $50+$ market.
One thing is for sure: we have not seen or heard the last of the baby boomer market, its importance and opportunities.

\section{References}

1 Thompson, A. (2005) 'Baby boomers create new marketing frontier', MSNBC.com, 17th March, http://www.msnbc.msn.com/id/7211153/, accessed 1st July, 2005.

2 Brown, D. (2005) 'Market handoff begins: As your bread-and-butter (the baby boomer) starts leaving the market, prepare to court your next customer: Generation Y', Dealernews, February, www.findarticles.com/p/articles/mi_m3323/is_2_41/ ai_nl3469786/, accessed 29th September, 2005.

3 Peterson, T. (2005) 'Marketing's boomer revolution?' BusinessWeek Online, 5th January, http://www.businessweek.com/bwdaily/dnflash/ jan2005/nf2005015_6056_db061.htm, accessed 29th September, 2005

4 Ibid.

5 Davis, K. (2005) 'Oldies but goodies. Marketers, take note: Baby boomers have lots of money to spend', USNews.com, 14th March, http://www.usnews.com/usnews/biztech/articles/ 050314/14boomer.htm, accessed 1st July, 2005

6 Coy, P. and Brady D. (2005) 'Old. Smart. Productive', BusinessWeek Online, http://www. businessweek.com/magazine/content/05_26/ b3939001_mz001.htm, accessed 17th June, 2005.

7 Ibid.

8 DiSanto Jones, L. (2004) 'Selling to the mature market', Advisor Today, Vol. 99, (April), p. 36-40.

9 Corke, K. (2005) 'Selfless baby boomers switch careers', $M S N B C, 23$ rd June, from http://www.msnbc.msn.com/id/8335831/, accessed 1st July, 2005.

10 Ibid.

11 Weimann, G. (2005) 'Marketing to baby boomers makes sense', ASHA Leader, Vol. 10, No. 9, p. 21.

12 Coy and Brady (2005), op. cit.

13 Ibid.

14 Davis (2005), op. cit.

15 Ibid.

16 Coy and Brady (2005), op. cit.

17 Ibid.

18 Ibid.

19 Ibid.

20 Ibid.

21 Ibid.

22 Timmermann, S. (2004-2005) 'Finding the gold in the silver industries: Business in transition', Journal of the American Society on Aging, Vol. 28, No. 4, http://www.generationsjournal.org/gen28-4/toc.cfm, accessed 17th June, 2005.

23 Elan, E. (2005) 'As baby boomers mature, industry may find that market, though aged, primed for more', Nation's Restaurant News, Vol. 39, No.8, p. 53. 
24 Embrey, A. (2005) 'Aging with grace', Convenience Store News, Vol. 41, No. 7, May, p. 57.

25 Ibid.

26 Ibid.

27 Kuehner-Hebert, K. (2004) 'Marketing lesson: Avoid the word seniors', American Banker, Vol. 169, January, p. 6A.

28 Ibid.

29 Crain, K. (2004) 'Young is good; old might be better', Automotive News, Vol. 78, 2nd February, p. 12.

30 Halliday, J. (2004) 'Buick sets its sights on boomers with new models', Advertising Age, Vol. 75, November, p. 4

31 Greenberg, K. (2005) 'Avalon effort suggests a different sort of trip', Brandweek, Vol. 46, No. 6, February, p. 6.

32 Winter, D. (2005) 'Choppers, not walkers', Ward's Auto World, Vol. 41, February, p. 7, http://waw.wardsauto.com/ar/auto_choppers_not_ walkers_2/index.htm, accessed: 17th June, 2005.

33 Ibid

34 Ibid.

35 McMillan, P. (2005) 'New approach needed on products for older people', MoneyMarketing, www.moneymarketing.co.uk, accessed 17th June, 2005.

36 Ibid.

37 New York Times (2005) 'Saying hello to baby boomers', www.nytimes.com, accessed 19th June, 2005.

38 Stroud, D. (2005) 'Sea change for silver surfers', Brand Strategy, Vol. 191, April, p. 52.

39 Ibid.

40 AdAge.com (undated) 'Study zeroes in on 50+ market's brand buying habits', http://www.adage.com/MarketingIntel/pdf/ AARP1.pdf, accessed 17th June, 2005.

41 Wolfe, D. B. (2004-2005) 'The changing psychology of the older consumer: The myth of aging boomers' differences from their parents', Journal of the American Society on Aging; http://www. generationsjournal.org /gen28-4/toc.cfm, accessed 17th June, 2005.

42 Coy and Brady (2005), op. cit.

43 Rosinski, J. (2005) 'Seniors and baby boomers are building serious credit card debt', Boston Herald, 21st March, http://www.newstarget.com/005941.html, accessed 1st July, 2005.

44 Ibid.

45 News Target.com (2005) 'Older couples will be forced to absorb more health care costs over next 20 years, report says', http://www. newstarget.com/ 006490.html. (accessed: 1st July, 2005).

46 Boyer King, E. (2004) 'Engaging the aging: Marketing to Europe's seniors', Brandchannel.com, September, http://www. brandchannel.com/ features_effect.asp?pf_id=228 accessed 18th June, 2005

47 Ibid.

48 Ibid.

49 Uranaka, T. (2005) 'Baby boomers poised to turn pensioners en masse', The Japan Times, 21st June, http://www.japantimes.co.jp/cgi-bin/getarticle. pl5?nn20050621f1.htm, accessed: 1st July, 2005.

50 Ibid.

51 Ibid.

52 Nyren, C. (2005) 'Don't talk so fast to baby boomers', Broadcasting \& Cable, 9th May, http://www.broadcastingcable.com/ article/CA600021.html?display=Opinion, accessed 29th September, 2005.

53 Ibid.

54 Moxley, M. (2004) 'Tech firms neglect older generation: Enormous potential', Financial Post, 25th October, FP 1.

55 Ibid.

56 Prewitt, M. (2005) 'Demographers: Industry can't shy away from retiring guests', Nation's Restaurant News, Vol. 39, 7th February, p. 6.

57 Coming of Age Incorporated (2005) 'Profitable strategies for baby boomer and older consumer market', http://www.comingofage.com, accessed 1st July, 2005.

58 Kuehner-Hebert (2004) op. cit.

59 Ibid.

60 Coming of Age Incorporated (2005), op. cit.

61 Coy and Brady (2005), op. cit.

62 Kuehner-Hebert (2004) op. cit.

63 Ebenkamp, B. (2004) 'Think granny don't surf?', Brandweek, Vol. 45, 27th September, p. 30.

64 Weimann (2005), op. cit.

65 Surowiecki, J. (2002) 'The financial page: Ageism in advertising (The Talk of the Town)', The New Yorker, 1st April, Vol. 78, No. 6, p. 40, available from http://www.newyorker.com/talk/content/ ?020401ta_talk_surowiecki, accessed 29th September, 2005.

66 Morgan, C. M. and Levy, D. J. (2002) Marketing to the Mindset of Boomers and Their Elders. Paramount Market Pub, Saint Paul, MN.

67 Ibid. 